\title{
Effect of Service Quality and Price Fixing Hajj Guidance Group to The Satisfaction of Congregation Perform The Pilgrimage
}

\author{
$1^{\text {st }}$ Muhammad Hanafi Zuardi ${ }^{1}, 2^{\text {nd }}$ Tantan Hermansah ${ }^{2}, 3^{\text {rd }} \mathrm{JM}$ Muslimin, and \\ $4^{\text {th }}$ Rahman Ahdari ${ }^{4}$ \\ \{muhammad.hanafi.zuardi@metrouniv.ac.id ${ }^{1}$, tantan.hermansah@uinjkt.ac.id ${ }^{2}$, muslimin@uinjkt.ac.id ${ }^{3}$, \\ sahabatrahman2014@gmail.com ${ }^{4}$ \} \\ Graduate School Sy arif Hiday atullah State Islamic University of Jakarta, Indonesia ${ }^{1234}$
}

\begin{abstract}
This study was conducted to test the hypothesis whether there is an effect of $\mathrm{KBIH}$ service quality on congregational satisfaction, also to test the hypothesis whether the effect of price fixing given by KBIH on congregational satisfaction and to analyze how much influence simultaneously the service quality and pricing given by $\mathrm{KBIH}$ on the satisfaction of pilgrims performing the pilgrimage. This type of research is a survey research that makes the behavior of the hajj organizers who are affiliated in 3 (three) $\mathrm{KBIH}$ in the Metro city of the Haj season in 2018. The nature of the research is quantitative with a statistical approach. The data was collected by distributing questionnaires and questionnaires using a Likert scale which were then tested for validity and reliability. The population in this study amounted to 351 people. The sampling technique used the Slovin formula with 187 samples. The data analy sis technique uses multiple linear regression analysis which previously carried out the classical assumption test including linearity test and normality test. After using multiple regression analysis, the hypothesis is tested using the $\mathrm{t}$ test and the $\mathrm{F}$ test and knowing the Adjusted $\mathrm{R}$ Square. Based on multiple regression analy sis with the equation $\mathrm{y}=5.072+0.268 \mathrm{X} 1+0.448 \mathrm{X} 2$, the results of this study are: 1) there is a significant effect of service quality on congregation satisfaction with a value of $t=4.196 ; 2$ ) there is a significant effect of pricing on congregation satisfaction with a value of $t=6,525$; and 3) The magnitude of the effect of service quality and price setting simultaneously on the satisfaction of the $\mathrm{KBIH}$ congregation is low, only $36.7 \%$.
\end{abstract}

Keywords: Service Quality, Pricing and Congregation Satisfaction

\section{Introduction}

The last pillar of Islam, namely performing the pilgrimage, is a rule that Muslims are rarely able to carry out. Hajj is an obligation that must be performed for every capable muslin, both male and female. There is a value of responsibility in the pilgrimage, so for those who are 
able but do not fulfill it, that person $\operatorname{sins}^{1}$. Basic sharia commands for Haj according to S. AlImron; 97

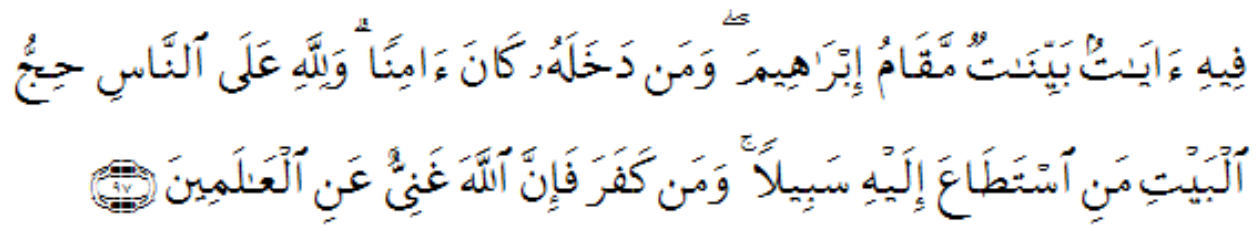

Meaning: in him there are real signs, (among them) the station of Abraham, whoever enters it (the Baitullah) is safe for him; Performing Hajj is a human obligation to Allah, namely (for) people who are able to travel to Baitullah. Whoever denies (obligatory hajj), then Allah is rich (does not need anything) from the universe ${ }^{2}$.

Various kinds of characteristics of Indonesian pilgrims, especially those who do not understand how the situation in Mecca is certainly something that must be anticipated, in this case the Ministry of Religion for Hajj and Umrah to anticipate it by paying intense attention. Many efforts have been made by the Director General of Hajj by escorting from the start of registration in their respective regions. However, it does not rule out the existence of several small groups that are trying to help ease the heavy burden on the Hajj director general himse lf. The small group in question is the presence of the Hajj Guidance Group or commonly abbreviated as $\mathrm{KBIH}^{3}$. In terms of workload, the existence of $\mathrm{KBIH}$ is indeed beneficial for the Director General of Hajj because there are many things that at least are able to unravel the accumulation of Hajj pilgrimages by the Director General of Haj but have been helped by the existence of $\mathrm{KBIH}$.

However, the existence of KBIH does not always provide convenience for the congregation, but also sometimes makes it difficult for prospective Indonesian pilgrims to come. Based on a survey that has been conducted by researchers to the Head of PHU Ministry of Religion, Metro City Mr. Drs. H Muhlisin, that many of the pilgrims, when it was determined by the Central Ministry of Religion to be dispatched and asked to make the rest of the payment, turned out that many of the prospective pilgrims ignored and did not even pay it because they failed to pay off and what was even more dangerous was due to the additional cost burden from the Hajj Guidance Group itself ${ }^{4}$.

Based on the results of temporary observations made by researchers regarding the implementation of the Hajj in the city of Metro in 2018, in general, prospective Metro pilgrims are divided into the two major groups. The first group is the ministry of religion group or commonly referred to as independent hajj pilgrims, and the second group is the KBIH congregation group. Most of the congregations who are members of the KBIH are spread across 5 (five) KBIH in Metro City. Seeing that there are some pilgrims who seem dis satisfied with the good services and services that will and have been accepted by the congregation as 
members, so that based on the illustration above, it appears a very complicated problem for prospective Indonesian pilgrims. On the one hand, the existence of $\mathrm{KBIH}$, however, needs to be evaluated both in terms of service quality, price fixing and congregational satisfaction with the two aspects mentioned above, so this is the importance of this research to be carried out. Therefore, the importance of doing this is to determine whether there is an effect of $\mathrm{KBIH}$ service quality on congregational satisfaction, then is there an effect of the price given by $\mathrm{KBIH}$ on congregation satisfaction and to analyze how much influence jointly between service quality and price provided by $\mathrm{KBIH}$ on congregation satisfaction in carrying out the pilgrimage.

Discussion

1. Hajj Guidance Group

It is an Islamic religious institution that organizes guidance for the pilgrimage as a government partner in the framework of organizing the pilgrimage nationally ${ }^{5}$. Organizationally, KBIH is a sub-ordinate of the Hajj Organizing Committee (PPIH) which has the duty and responsibility of assisting and serving the prospective guests of God, especially those who carry out the regular pilgrimage / regular BPIH while still in the country and when they arrive at Holy land.

The most recent law related to KBIH is Law of the Republic of Indonesia Number 8 of 2019 concerning the Implementation of Hajj and Umrah Worship Chapter V concerning Hajj and Umrah Guidance Groups Article 52 to Article 56.Some of the KBIH's obligations include:

a. Provide guidance to pilgrims;

b. Obey the statutory regulations regarding the implementation of the haj pilgrimage;

c. Coordinating and assisting the smooth running of the haj pilgrimage with related officials;

d. Sign a letter of agreement with the pilgrims that contains the rights and obligations of both parties;

e. Submit a list of guided pilgrims to the head of the local Ministry of Religion office;

f. Report guidance activities to the head of the local Ministry of Religion Office;

g. Emphasize national identity and not group identity. Then related to the main tasks of KBIH, namely:

a. Organizing / implementing additional Hajj guidance in the country as well as providing guidance;

b. Organizing / implementing field guidance in Saudi Arabia;

c. Carrying out consulting services, information and resolution of cases of worship for worshipers in Indonesia and Saudi Arabia;

d. To develop self-confidence in the mastery of the pilgrimage rituals that he / she guides;

e. Providing services that are directive, counseling and appeal to avoid things that can lead to jinayat haji (hajj violations).

As for the functions of KBIH include:

a. Implementing additional Hajj guidance in the country as training guidance;

b. Implementing field guidance in Saudi Arabia;

c. Services, consultations and information sources for the study 
d. Motivator for members of the congregation, especially in terms of mastery of the science of manasik, legality and perfection of the pilgrimage.

\section{Customer Satisfaction}

According to Philip Kotler, consumer satisfaction is a feeling of pleasure or disappointment for someone who appears after comparing the performance (results) of the product thought against the expected performance ${ }^{6}$. Conceptually, customer satisfaction can be interpreted are: Objectives, Products / Services, Product Value for Consumers, Consumer Needs and Desires and Consumer Expectations for Products / Services which all of which will lead to the Consumer Satisfaction Level.

Several factors affect customer satisfaction, namely ${ }^{7}$ :

a. Product quality; customers will feel satisfied if it shows that the product used is quality;

b. Quality of service or services; customers are satisfied when they get good service or as expected.

c. Emotions; customers feel proud and get confidence that other people will be amazed by them when using products with certain brands that tend to have higher levels of satisfaction.

d. Price, namely products that have the same quality but set a relatively cheap price will provide higher value to customers.

e. Costs, customers who do not need to pay additional costs or do not need to waste time to get a product or service tend to be satisfied with the product or service.

From the five descriptions above, in this study the researcher only used 2 (two) factors which are thought to be able to influence the satisfaction of congregation in the three KBIH Metro cities, namely service quality and price setting. Three main components of customer satisfaction, namely ${ }^{8}$ :

a. Response (Type and Intensity); is an emotional response as well as cognitive.

b. Focus; focus on the performance of objects adjusted to several standard values.

c. Response time; happened at a certain time.

Some of the characteristics of satisfied consumers include: ${ }_{-}^{9}$

a. Product loyalty;

b. Positive word of mouth communication;

c. The company is a major consideration when buying other brands .

According to Kotler, customer expectations when buying actually consider the product's function (product performance), among others: ${ }_{-}^{10}$

a. Products perform better than expected, which is called positive disconfirmation; 
b. The product works as expected, which is called a simple confirmation;

c. The product is performing worse than expected, so it is called a disconfirmation;

d. Negative (negative disconfirmation), disappointment because you are not satisfied.

\section{Quality of Service}

Service is any action or performance that one party can offer to another, which is basically intangible and does not result in ownership of something. The production may or may not be related to the physical product ${ }^{11}$. Some of the characteristics of the service include $^{12}$ : Intangible; Inseparability; Variability; Perishability; services as commodities that are not durable and cannot be stored. Several service models in the service business can be interpreted as follows; Smile to consumers, friendly, polite and outgoing, do things better, reach out and approach guests with all kindness, invite consumers to come back. This Word document can be used as a template for papers to be published in EAI Core Proceedings. Follow the text for further instructions on text formating, tables, figures, citations and references.

Service quality is defined as dynamic conditions associated with products, services, human resources, processes and the environment that meet or exceed expectations ${ }^{13}$. Kotler and Keller stated that service quality must begin with customer needs and end with customer perceptions, where customer perceptions of service quality are a comprehensive assessment of the excellence of a service. According to Tijptono, the dimensions of service quality are as follows ${ }^{14}$ : tangible evidence, reliability, responsiveness, assurance and empathy.

\section{Pricing}

According to Philip Kotler, price is the amount of value or money charged for a product or service for the amount of value that consumers exchange for price benefits which have become an important factor influencing buyer choice, this applies in poor countries, but non-price factors. has become more important in the behavior of choosing buyers in this decade (10 years), so that in a narrow sense it can be explained that the definition of price is the amount of money charged for a good or service ${ }^{15}$. Referring to the opinions of Kotler and Keller, there are 5 main objectives of pricing, among others ${ }^{16}$ : life sustainability, maximum profit now, maximum market share, maximum market control, product quality leadership, Other Purposes. According to Kertajaya, indicators of price include the suitability of product prices with product quality, and product price suitability with benefits obtained. 
5. Research Instruments

Test the validity and reliability of the questionnaire in this study using the help of the SPSS 22 software application.

Table 1:

Research Questionnaire Validity Test

\begin{tabular}{|c|c|c|c|c|}
\hline No & Questions / Indicators & $\mathrm{r}$ table & r count & Inf \\
\hline \multicolumn{5}{|c|}{ Quality of Service } \\
\hline 1. & $\begin{array}{l}\text { High integrity and ability to use Hajj supporting } \\
\text { facilities }\end{array}$ & 0,1200 & 0,916 & Valid \\
\hline 2. & $\begin{array}{l}\text { Quality of knowledge of KBIH Officers Information } \\
\text { and Service Responsibility }\end{array}$ & 0,1200 & 0,911 & Valid \\
\hline 3. & HR responsif & 0,1200 & 0,886 & Valid \\
\hline 4. & HR communicative & 0,1200 & 0,838 & Valid \\
\hline 5. & Politeness & 0,1200 & 0,862 & Valid \\
\hline \multicolumn{5}{|c|}{ Pricing } \\
\hline 1. & Compensation Receipt & 0,1200 & 0,827 & Valid \\
\hline 2. & General Authority Decree of the Minister of Religion & 0,1200 & 0,886 & Valid \\
\hline 3. & Value Benefit and Justice & 0,1200 & 0,884 & Valid \\
\hline 4. & References, assumptions and final prices & 0,1200 & 0,871 & Valid \\
\hline 5. & Purchasing Power and Financial Capability & 0,1200 & 0,886 & Valid \\
\hline \multicolumn{5}{|c|}{ Satisfaction of the Jamaah } \\
\hline 1. & Service quality as desired & 0,1200 & 0,854 & Valid \\
\hline 2. & Set prices in accordance with financial capabilities & 0,1200 & 0,891 & Valid \\
\hline 3. & No complaints & 0,1200 & 0,869 & Valid \\
\hline 4. & $\begin{array}{l}\text { Return to using KBIH if you have the opportunity } \\
\text { again }\end{array}$ & 0,1200 & 0,876 & Valid \\
\hline 5. & Recommend to the closest family & 0,1200 & 0,888 & Valid \\
\hline
\end{tabular}

Reliability test on the 3 variables tested, namely congregational satisfaction, service quality and pricing can be seen in the following table:

Table 2:

Results of the Research Questionnaire Reliability Test

\section{Reliability Statistics}

\begin{tabular}{c|r}
$\begin{array}{c}\text { Cronbach's } \\
\text { Alpha }\end{array}$ & N of Items \\
\hline, 750 & 3 \\
\hline
\end{tabular}

Source: Data Processed With SPSS 22

Classic Assumptions

Normality test

The results of the normality test in this study are as follows: 


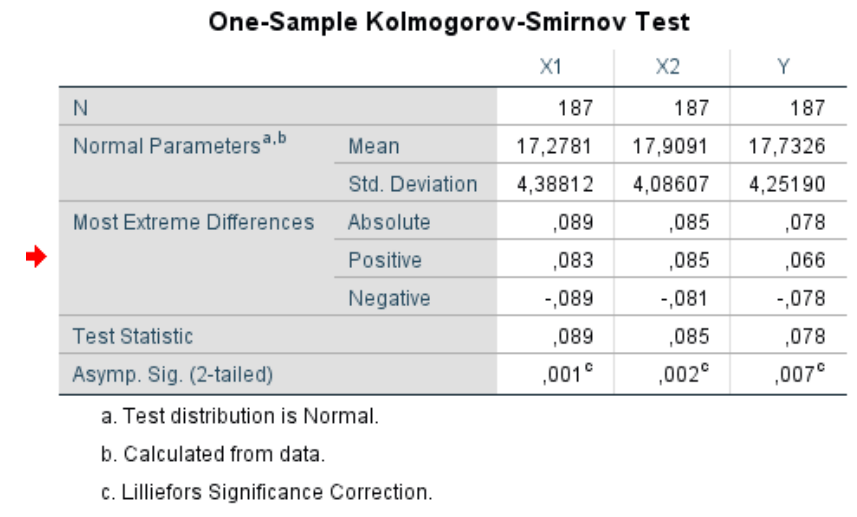

Linearity Test

Linearity test uses the SPSS 22 program using the compare means function are follows:

Table 3:

Linearity Test Results of Service Quality Variables ANOVA Table

\begin{tabular}{|c|c|c|c|c|c|c|c|}
\hline & & & $\begin{array}{l}\text { Sum of } \\
\text { Squares }\end{array}$ & df & Mean Square & $\mathrm{F}$ & Sig. \\
\hline \multirow[t]{5}{*}{$Y * X 1$} & \multirow[t]{3}{*}{ Between Groups } & (Combined) & 982,683 & 15 & 65,512 & 4,707 &, 000 \\
\hline & & Linearity & 768,374 & 1 & 768,374 & 55,208 &, 000 \\
\hline & & Deviation from Linearity & 214,309 & 14 & 15,308 & 1,100 &, 361 \\
\hline & Within Groups & & 2379,948 & 171 & 13,918 & & \\
\hline & Total & & 3362,631 & 186 & & & \\
\hline
\end{tabular}

Based on the results of the linearity test on the output table "Anova Table: above, it is known that the sig.Deviation form Linearity value is 0.361 . Because the Sig. 0.361>0.05, it can be concluded that there is a linear relationship between service quality variables and congregation satisfaction variables.

Table 4:

Results of the Linearity Test of Pricing Variables ANOVA Table

\begin{tabular}{|c|c|c|c|c|c|c|c|}
\hline \multicolumn{8}{|c|}{ 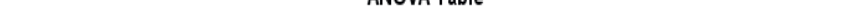 } \\
\hline & & & $\begin{array}{l}\text { Sum of } \\
\text { Squares }\end{array}$ & $\mathrm{df}$ & Mean Square & $\mathrm{F}$ & Sig. \\
\hline \multirow[t]{5}{*}{$Y * X 2$} & Between Groups & (Combined) & 1154,554 & 16 & 72,160 & 5,556 &, 000 \\
\hline & & Linearity & 1054,314 & 1 & 1054,314 & 81,172 &, 000 \\
\hline & & Deviation from Linearity & 100,240 & 15 & 6,683 &, 514 & 930 \\
\hline & Within Groups & & 2208,077 & 170 & 12,989 & & \\
\hline & Total & & 3362,631 & 186 & & & \\
\hline
\end{tabular}

Based on the results of the linearity test on the output table "Anova Table: above, it is known that the sig.Deviation form Linearity value is 0.930. Because the Sig. 0.930>0.05, it can be concluded that there is a linear relationship between the price setting variable and the congregational satisfaction variable.

Multiple Linear Regression Analysis

Table 5:

Multiple Linear Regression Results 


\begin{tabular}{|c|c|c|c|c|c|c|}
\hline \multicolumn{7}{|c|}{ Coefficients $^{a}$} \\
\hline & & \multicolumn{2}{|c|}{ Unstandardized Coefficients } & \multirow{2}{*}{$\begin{array}{c}\text { Standardized } \\
\text { Coefficients } \\
\text { Beta }\end{array}$} & \multirow[b]{2}{*}{$t$} & \multirow[b]{2}{*}{ Sig. } \\
\hline & & B & Std. Error & & & \\
\hline \multirow[t]{3}{*}{1} & (Constant) & 5,072 & 1,235 & & 4,107 &, 000 \\
\hline & $\mathrm{X} 1$ & .268 & .064 & .277 & 4,196 &, 000 \\
\hline & $\mathrm{X} 2$ & .448 &, 069 & ,431 & 6,525 &, 000 \\
\hline
\end{tabular}

a. Dependent Variable: $Y$

Based on data analysis using the SPSS 22 program, the regression equation is obtained as follows: $\mathrm{Y}=5.072+0.268 \mathrm{X} 1+0.448 \mathrm{X} 2$

From the above equation, it means that the resulting constant value is 5.072 , indicating that if the variable value of service quality and price setting is considered constant, then the congregational satisfaction level at KBIH is 5.072.

The service quality regression coefficient value is 0.268 , which means that the service quality has a positive effect on the satisfaction of the congregation using KBIH services because the variable regression coefficient is positive. This means that for each increase in the value of service quality by 1 unit, the satisfaction of the KBIH congregation will increase by $0.268 \%$. This means that the better the quality of service, the higher the satisfaction level of the KBIH congregation.

The value of the price fixing regression coefficient is 0.448 , which means that the price fixing has a positive effect on congregational satisfaction in the KBIH because the variable regression coefficient is positive. This means that for each increase in the value of the price setting by 1 unit, the satisfaction of the congregation at $\mathrm{KBIH}$ will increase by $0.448 \%$. This means that the better the pricing of food, the higher the satisfaction level of the KBIH congregation

\section{Determination Coefficient Test}

This test is carried out to predict and see how much influence the contribution of service quality (x1) and price-setting variables (x2) simultaneously (together) to the variable of congregational satisfaction $(\mathrm{y})$

Table 6

Test Results for the Determination Coefficient Test (R Square)

\begin{tabular}{|c|c|c|c|c|}
\hline \multicolumn{5}{|c|}{ Model Summary' } \\
\hline Model & $\mathrm{R}$ & R Square & Adjusted R Square & $\begin{array}{l}\text { Std. Error of the } \\
\text { Estimate }\end{array}$ \\
\hline 1 &, $611^{a}$ &, 373 &, 367 & 3,38375 \\
\hline
\end{tabular}

Based on table 6 above, it can be seen that the coefficient of determination is 0.367 which means that the contribution of the variable service quality and pricing in explaining the satisfaction of pilgrims is low because only $36.7 \%$ of the service quality and pricing variables can affect the satisfaction of the congregation, while the rest $63.3 \%$ is influenced by other factors not discussed in this study.

Hypothesis testing 
Simultaneous Test with F-Test (Anova)

This test is conducted to test whether there is an effect of service quality and price setting simultaneously on the variable of congregational satisfaction

Table 7:

F Test Results

ANOVA $^{\mathrm{a}}$

\begin{tabular}{ll|r|r|r|r|r} 
Model & & Sum of Squares & df & Mean Square & F & \multicolumn{1}{c}{ Sig. } \\
\hline 1 & Regression & 1255,872 & 2 & 627,936 & 54,843 &, $000^{\text {b }}$ \\
\cline { 2 - 8 } & Residual & 2106,759 & 184 & 11,450 & & \\
\hline & Total & 3362,631 & 186 & & & \\
\hline
\end{tabular}

a. Dependent Variable: $Y$

b. Predictors: (Constant), $X 2, \mathrm{X} 1$

Based on table 7 above, it can be explained by using a significance level of 0.05 obtained F count of 54.843 with F table of 3.040 thus F count $>$ F table with a significance level obtained $0.000<0.05$ so that together the quality of service and determination Price has a simultaneous effect on congregational satisfaction at KBIH in Metro city, Lampung Province. Partial Test with T-Test

To see the effect of the independent variable on the dependent variable itself, the instrument used was the t test statistic. Testing the regression coefficient with a confidence level of $95 \%$ (significant level 5\%) and $\mathrm{df}=\mathrm{n}-3$, then the t table obtained is 1.984 .

Table 8:

Hypothesis Testing Results

Coefficients $^{\mathrm{a}}$

\begin{tabular}{|c|c|c|c|c|c|c|}
\hline \multicolumn{7}{|c|}{ Coefficients $^{\mathrm{a}}$} \\
\hline \multirow[b]{2}{*}{ Model } & \multicolumn{3}{|c|}{ Unstandardized Coefficients } & \multirow{2}{*}{$\begin{array}{c}\text { Standardized } \\
\text { Coefficients } \\
\text { Beta }\end{array}$} & \multirow[b]{2}{*}{ t } & \multirow[b]{2}{*}{ Sig. } \\
\hline & & B & Std. Error & & & \\
\hline \multirow[t]{3}{*}{1} & (Constant) & 5,072 & 1,235 & & 4,107 & .000 \\
\hline & $\mathrm{x} 1$ & 268 & .064 & ,277 & 4,196 & .000 \\
\hline & $\times 2$ & .448 & ,069 & .431 & 6,525 & .000 \\
\hline
\end{tabular}

Based on table 8 above, it can be explained that the quality of service has a significant effect on the satisfaction of the KBIH congregation in Metro City because $t$ count $=4.196>t$ table $=1.984$ and a significance value of 0.000 ( $\mathrm{sig}<0.05)$. Based on the above analysis, it can be concluded that the service quality variable (x1) has a significant effect on the satisfaction of the KBIH Metro City congregation.

Based on table 8 above, it shows that the regression coefficient of the service quality variable is 0.268 and is positive with a significant probability level of 0.000 with a significant probability value <alpha, which is 0.05 . Thus these results indicate the better the quality of $\mathrm{KBIH}$ services, the more satisfaction of the KBIH congregation in Metro Lampung city will be increased.

Based on table 8 above, it can be explained that pricing has a significant effect on the satisfaction of the KBIH congregation in Metro City because $t$ count $=6,525>\mathrm{t}$ table 1.984 and a significance value of 0,000 ( $\mathrm{sig}<0.005$ ). Based on the above analysis, it is concluded that the price setting variable (X2) has a significant effect on the satisfaction of the KBIH congregation in Metro city.

Based on table 8 above, it shows that the regression coefficient of the pricing variable is 0.448 and is positive with a significant probability level of 0.000 with a significant 
probability value <alpha, which is 0.05 . Thus these results indicate that the better the price setting, the greater the satisfaction level of the KBIH Jamaah in Metro city Based on the results of the descriptive analysis it is known that of the 187 respondents studied who were the third congregation of $\mathrm{KBIH}$, namely Armina Jadid, al Hikmah and Arofah Muhammadiyah, were men who were more than 67 years old with a job as a retiree with an average income of $\geq$ IDR $10,000,000$.

The effect of service quality and pricing on congregational satisfaction at the three KBIHs in Metro City can be seen using regression analysis techniques. Based on the results of multiple linear regression analysis, it is known that service quality has a positive and significant effect on congregational satisfaction in the three KBIH Metro cities. This is known from the acquisition of the value of $t$ count $>t$ table (4.196>1.984) with a significance of 0.000 and a regression coefficient value of 0.268 which is positive.

Based on the results of multiple linear regression analysis on the effect of price setting on the satisfaction of pilgrims in the three KBIH of Metro City, it is known that price setting has a positive and significant effect on congregational satisfaction in the three KBIH of Metro City. This can be seen from the acquisition of the value of $t$ count $>t$ table $(6,525>1.984)$ with a significance of 0.000 and a regression coefficient value of 0.448 which is positive. From the results of the regression analysis, it can also be seen that the quality of service and pricing can only affect the satisfaction of the congregation in the three KBIH Metro cities by $36.7 \%$ (ajusted $\mathrm{R}^{2}$ value). In other words, there is the influence of other variables of $63.3 \%$ which are not measured in this study. The variable ability of service quality and price setting can be said to be weak, because several other variables must be considered in measuring congregational satisfaction. Broadly speaking it can be explained that the implementation of service quality and price fixing carried out by the three $\mathrm{KBIH}$ metro cities is only able to provide a small contribution to the creation of friendly satisfaction with the services they get, this of course has a negative influence on the continuity of the city's Hajj Pilgrimage Guidance Group foundation. Metro.

\section{CONCLUSION}

1. There is a significant effect of the quality of services provided by KBIH on congregational satisfaction

2. There is a significant influence between the pricing given by $\mathrm{KBIH}$ on congregation satisfaction.

3. The magnitude of the effect of service quality and price fixing simultaneously on the satisfaction of the KBIH Metro congregation is $36.7 \%$, which means that service quality and price have a low effect on congregational satisfaction.

\section{BIBLIOGRAPHY}

[] AhmadLate Muhammad Moinuddin Ahmad, A Handbook of Hajj and Umrah an English Version of Masai'l-o-Ma'lumat-e-Hajj-o-Umrah (The Rules and Ceremonies of Hajj and Umrah) What to Do? Where to Do? What Not to Do?How to Do? (Pakistan: The Goverment of Pakistan, Ministry of Religous Affairs Is lamabad, 1984), 13.

[2] Departemen Agama RI, "Syaamil Al-Qur'an," in Al-Qur'an Terjemah Per-Kata (Bandung: Syaamil International, 2007).

[3] Ekbisi; Widyarini, "Manajemen Kelompok Bimbingan Ibadah Haji (KBIH)," Ekbisi, no. Vol 7, No 2 (2013): Jurnal Ekonomi dan Bisnis Islam (2013), http://ejournal.uin suka.ac.id/index.php/Ekbisi/article/view/334. 
[4] Pre Survey with Drs. Muhlisin as Head of PHU Ministry of Religion of Metro City, Interview on Monday, August 132018 in the Sie PHU Office Room of the Ministry of Religion of Metro City

[5] RI Minister of Religion Decree No. 396 of 2003 concerning Amendments to the Decree of the Minister of Religion of the Republic of Indonesia No. 371 of 2002 concerning the Implementation of Hajj and Umrah Worship Article 1. Prior to 2003, Hajj guidance institutions existed but had not been regulated by the Government. From several existing histories, most of the KBIHs that were established were individual or family institutions that were not legally incorporated and only relied on experience and networks in the land of Haram (Mecca)

${ }^{[6]}$ Philip Kotler et al., Principles of Marketing Second European Edition, First Euro. (Rotolio Lombards, Milan, Italy: Prentice Hall Inc. A Simon \& Schuster Company Upper Saddle River New Jersey, USA, 1999).

[7] Richard L Oliver, Satisfaction A Behavioral Perspective On The Consumer, McGraw-Hill, New York, 2nd Editio. (New York, USA: Routledge Taylor \& Francis London and New York, 1997)

[8] Giese and Cote, "Defining Customer Satisfaction," Academy of Marketing Science Review 2000, no. 1 (2000), http://www.ams review.org/articles/giese01-2000.pdf.

[9] Philip Kotler and Kevin Lane Keller, Marketing Management, ed. Katie Stevens and Will Mara, Pearson Education,Inc., Upper Saddle River, New Jersey 07458, Twelfth Ed. (Upper Saddle River, New Jersey: Pearson Prentice Hall, 2006), 57.

[10] John Saunders and Veronica Wong Philip Kotler, Gary Armstrong, Principles of Marketing, Second European Edition, 2nd Europe. (Italy, Rotolio Lombards, Milan: Prentice Hall Europe, 1999).

${ }^{[11]}$ Philip Kotler and Kevin Lane Keller, Marketing Management, Organization, Twelve Edi. (Upper Saddle River, New Jersey 07458: Pearson Prentice Hall, 2006), 111

[12] A Parasuraman, Valarie A Zeithaml, and Leonard L Berry, "A Conceptual Model of Service Quality and Its Quality and Implications for Future Research," The Journal of Marketing 49, no. 4 (2016): 118, http://www.jstor.org/stable/1251430.1 